\title{
Environmental Education in Micro and Small Enterprises: Innovation for Sustainability
}

\author{
César Leandro de Christo Hundertmarck ${ }^{1}$, Raimundo Claudio Gomes Maciel ${ }^{1}$, \\ Geane de Oliveira Januário², Clarides Henrich de Barba ${ }^{3}$, Fernanda Goelzer Pereira Bini4, \\ Valmir Francisco dos Santos ${ }^{5}$, Bianca Morais Mendes ${ }^{3}$, Marco Venício da Silva Pereira ${ }^{6}$, \\ Gerdalva de Araújo de Vasconcelos ${ }^{3}$
}

\author{
${ }^{1}$ Universidade Federal do Acre-UFAC, Rio Branco, Brazil \\ ${ }^{2}$ Universidade Federal do Paraná-UFPR, Curitiba, Brazil \\ ${ }^{3}$ Fundação Universidade de Rondônia-UNIR, Porto Velho, Brazil \\ ${ }^{4}$ Instituto Federal de Rondônia-IFRO, Cacoal, Brazil \\ ${ }^{5}$ Instituto Federal de Rondônia-IFRO, Ariquemes, Brazil \\ ${ }^{6}$ Instituto Federal de Rondônia-IFRO, Jaru, Brazil \\ Email: cesarlch@ufac.br, rcgmaciel@ufac.br, geane.ufac@gmail.com, clarides@unir.br, goelzer.fer@gmail.com, \\ valmir.santos@ifro.edu.br, biancamoraismendes@gmail.com, marco.pereira@ifro.edu.br, gerdalvavasconcelos@hotmail.com
}

How to cite this paper: de Christo Hundertmarck, C. L., Maciel, R. C. G., de Oliveira Januário, G., de Barba, C. H., Bini, F. G. P., dos Santos, V. F., Mendes, B. M., da Silva Pereira, M. V., \& de Araújo de Vasconcelos, G. (2019). Environmental Education in Micro and Small Enterprises: Innovation for Sustainability. Creative Education, 10, 922-939.

https://doi.org/10.4236/ce.2019.105069

Received: April 2, 2019

Accepted: May 18, 2019

Published: May 21, 2019

Copyright $\odot 2019$ by author(s) and Scientific Research Publishing Inc. This work is licensed under the Creative Commons Attribution International License (CC BY 4.0).

http://creativecommons.org/licenses/by/4.0/

\begin{abstract}
The corporate world has already realized the importance of allying profit generation and social and environmental responsibility in its production processes, as a way to remain competitive in the market, as consumers are more and more aware of the importance of acquiring products and services with added environmental value. In this context, micro and small companies appear as units that are able to adapt to this new market demand, further increasing their contribution to the Brazilian economy. The purpose of this article is to analyze environmental education as a competitive differential for small businesses. The research problem that guides the study is the following: is environmental education an innovation tool that can contribute to reducing the mortality rate of micro and small enterprises? We work with the hypothesis that environmental education contributes to increasing the profitability of micro and small companies, from the moment that it contributes to improving the image of the business for society, demonstrating that the products and services offered meet the performance standard established by the certifying unit, as well as informing the origin of the products and the techniques of production.
\end{abstract}

\section{Keywords}

Environmental Education, Micro and Small Enterprises, Innovation, Sustainability, Environmental Certification 


\section{Introduction}

Micro and Small Enterprises (MPEs) play an unquestionable role in the economic development of a country, both by generating formal jobs and generating income. In Brazil, how could it be different from the rest of the world, and how can smal lbusinesses stand out as one of the main drivers of the locale conomy?

In the segment of micro-enterprises and small enterprises, a large part of the labor force is concentrated in the labor market. Part of this is the need for a differentiated look at these business units that play a fundamental role for the Brazilian economy. The predominant presence of smaller companies is a result of the trend of increasing participation of micro and small enterprises in the total number of establishments and in employment over the last years, contributing significantly to the composition of gross domestic product.

In order to corroborate what was previously argued, the following data prove the relevance of micro and small companies in the generation of employment in Brazil. 115,900 formal work posts were created in April 2018, according to data from the General Register of Employed and Unemployed (CAGED, 2018). The micro and small enterprises (MPE) created 83,500 places in that month, which corresponds to $72 \%$ of the formal jobs generated. In the first four months, MPEs accumulated 293 thousand formal jobs, almost double the accumulated in the same period in 2017 (155.5 thousand) (Sebrae, 2018).

Following a similar trend to the increase in formal jobs, it was noticed that in the environmental context, there was also a growth of companies that sought ISO 14001 certification in Brazil, since from 2013 until 2018 there was an increase in these certifications, as can be seen in Figure 1. This increased certifications and also the jobs generated confirm the importance of environmental education in the sustainability of micro and small enterprises and income generation (formal jobs) in the Brazilian economic context. In this way, companies have awakened to environmentally responsible procedures and attitudes in the manufacturing environment and also in the provision of services

In recent years, due to the great pressure and social mobilization, companies started to adopt sustainable processes. The inclusion of the sustainability agenda in the business world has been verified in all business segments, both nationally and internationally. This change in corporate behavior did not occur free of charge, but rather as a way to increase profitability and ensure market survival.

In this scenario, it is essential to include micro and small companies in this new social and market demand for the aggregation of sustainable value to the products and services offered to consumers. The globalization of markets, the collection of consumers for sustainable environmental products and the concern for quality of life and preservation of the environment are growing demand and have become the competitive differential for companies investing in environmental certification.

To obtain environmental certification it is necessary to implement an environmental management system, through which the company starts to manage 


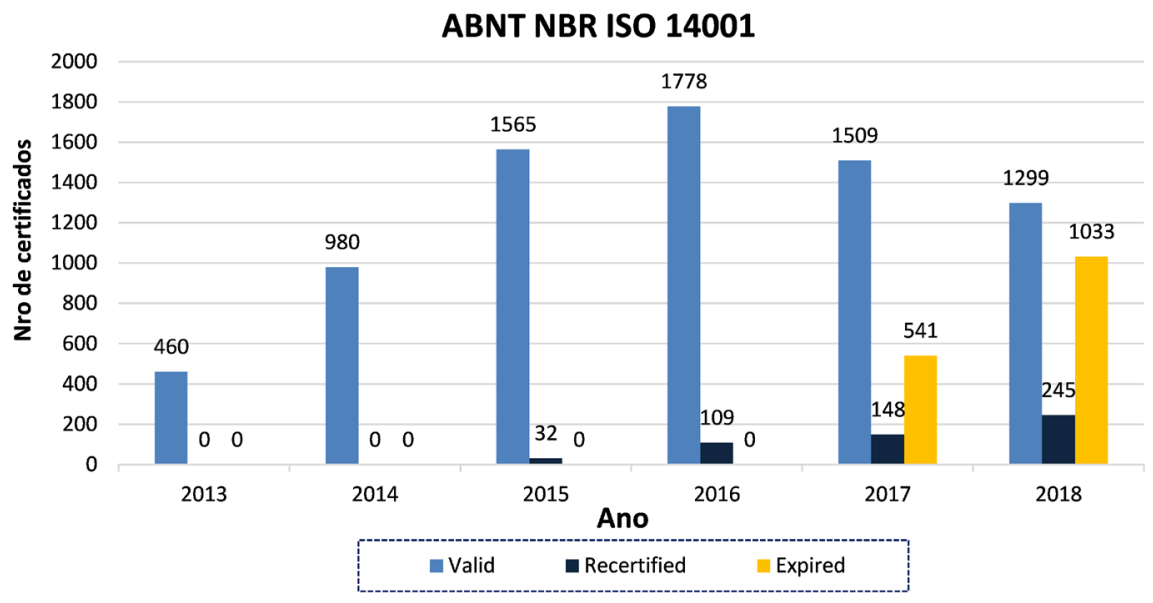

Figure 1. Growth of certification 14,001 in Brazil. Source: http://certifiq.inmetro.gov.br. Accessed 10/22/2018 (Certificados Válidos no Brasil, 2018).

the services and products they offer, as well as the processes they carry out, so as not to harm the environment. Such a management control mechanism directly influences the way companies are produced, making them acquire new machinery that contributes to reducing the emission of pollutants and offers products manufactured with raw material extracted in an environmentally correct way.

Companies that adopt environmental standards need to comply with the "International Organization for Standardization (ISO)” 14001 and have cost control and resources to make environmental management decisions. NBR ISO 14001 is voluntary and comprises a set of international environmental standards, which are not mandatory, that enable the achievement of Environmental Certification.

However, the environmental certification according to NBR ISO 14001 standards, has a high cost, which in most cases makes implantation in small enterprises unviable. Therefore, it is understood to be essential to comply with legislation regardless of the certification according to NBR ISO 14001. To do so, it is necessary to know the environmental norms, through environmental education, in which environmental control mechanisms can be developed, to help micro and small companies to adopt environmentally sustainable processes and to demonstrate to consumers their commitment to the environment and future generations. Such a measure may help to aggregate sustainable value to the products and services offered by micro and small enterprises, contributing to increase profitability and thus ensure survival in the market.

Environmental education is a foundation for the preservation and conservation of the environment. In this case, the adoptions of environmental norms directed to the company are characterized by the accomplishment of the planning focused on the environmental question, the control of the productive processes will take into account the impacts that they have caused to the environment. All decisions aim at a more efficient use of natural resources, in order to reduce environmental impacts (Santana \& Nunes, 2013).

In the current market scenario, the micro and small companies that stand out are the ones that adapt to the constant changes and invest in innovation. In this 
context, the innovation process emerges to help these enterprises to maintain and gain space in the market that is increasingly competitive. Innovation for the environment is a tool that can help small businesses to adhere to the environmentally sound production process, without, however, significantly increasing their production and marketing costs. On the contrary, the objective is to increase profit by producing sustainably (Sebrae, 2013a).

The research question that guides the work is that "Is environmental education an innovation tool that can contribute to reduce the mortality rate of micro and small enterprises?". We work as the hypothesis that environmental education contributes to increase the profitability of micro and small companies, from the moment that contributes to improve the image of the business before society, demonstrating that the products and services offered meet the standard of performance established by the certifying unit, as well as informing the origin of the products and the techniques of production.

In this context, this article aims to analyze environmental education as a competitive differential for small businesses.

Initially, it presents the environmental education and sustainability to next deal with the environmental certification and the ISO 14001. The fourth section contextualizes the origin of micro and small enterprises and their importance for the development of the Brazilian economy, and the fifth section relates the convergence of environmental education in micro and small enterprises as a factor of innovation and sustainability in the fifth section it is related to the innovation for the environment and micro and small enterprises, and the sixth section presents environmental marketing and the role of certification in the sustainability of micro and small enterprises.

\section{Environmental Education and Sustainability}

In recent years, concern about environmental issues has surfaced in society, both in the governmental dimension and in the private dimension. According to Giesta (2009) concern about environmental issues in the organizational sphere began to emerge between the 1970s and 1980s. As a consequence of this concern, several events were happening on the world environment scene.

At the United Nations Conference on the Human Environment held in Stockholm in 1972, instruments were introduced to institutionalize the environmental and social issue among nations by standardizing the criteria to be followed through the declaration on the human environment (Jacobi, Raufflet, \& Arruda, 2011).

In 1992, at the United Nations Conference on Environment and Development, held in Rio de Janeiro, it was recommended that environmental education be a priority for governments, entrepreneurs and society in general. At this Conference, the term sustainable development began to be widely disseminated, becoming more visible worldwide (UNESCO, 2014). Sustainable development is one that meets the needs of the present without compromising the ability of future generations to meet their own needs. Since the Rio de Janeiro Conference, 
there has been a more conscious change in the posture of society, which has been more attentive and linked to environmental issues, has started to charge companies for ecologically correct production and marketing. Such a change of position influenced directly in the business world, in which environmental management had a strategic role, being treated as an alternative to obtaining the balance between the profits propagated by the capitalist system and the preservation of the environment. The practice of environmental management is growing in the corporate world, contributing significantly to the change in production processes, as it aims to ensure interaction between the means of exploration, production and marketing of environmental resources and the profitability of companies (Layrargues, 1998; Quintas, 2004).

The actions focused on environmental management have gained a great deal of space in micro and small companies, especially after the partnership between the Brazilian Service of Support to Micro and Small Companies (Sebrae) and the Brazilian Association of Technical Standards (ABNT) access to the standards of ABNT NBR ISO 14005. This standard guides the process of implementation of the requirements set forth in ABNT NBR ISO 14001 (ABNT, 2004), for the implementation of the Environmental Management System (Sebrae, 2013a).

However, the effort was not enough to leverage the index of micro and small businesses that adhered to the environmental certification process. Therefore, it is essential to develop educational policies and practices that assist small businesses in the adequacy and compliance of environmental standards, as well as compliance with the main environmental practices in order to adjust the demand of the segment in which they operate, achieving thus maintaining market survival (Sebrae, 2013b).

In this scenario, environmental education stands out as an affordable and inexpensive tool for the small business segment, since it is offered free of charge by public institutions, including courses exclusively for micro and small entrepreneurs being offered by Sebrae, an institution focused on these enterprises, and that it has as a goal to work for the sustainable development of small businesses (Sebrae, 2013c).

In order to affirm its position regarding the importance of environmental education, the Brazilian government sanctioned in 1999, Law $\mathrm{n}^{\circ}$ 9795, of April 27 , which deals with environmental education and institutes the national policy of environmental education, and is established in art. 1st, the definition of environmental education "the processes through which the individual and the community construct social values, knowledge, skills, attitudes and competences aimed at the conservation of the environment, as well as the common use of the people, essential to the healthy quality of life and its sustainability" (Brasil, 1999: p. 1).

The environmental education thus enabled a preparation for the adjustments in search of the 14,001 certification and also an opportunity for micro and small companies that, due to organizational budgetary losses, could have problems in financing the implementation of the certification. 


\section{Environmental Certification and NBR ISO 14001}

Global awareness of the importance of environmental issues directly influenced the creation of environmental management standards: BS 7750 and the ISO 14000 series. The BS 7750 standard was published in 1992 with the aim of defining international norms for the creation, development and compliance of environmental rules and policies, serving as a basis for all segments of organizations. ISO 14000 was published in 1994 two years after the United Nations Conference on Environment and Development in Rio de Janeiro.

The ISO 14000 series standardized environmental standards and served as a beacon and stimulator for companies to become aware that it was time to adjust to the new environmental rules imposed by society. According to Giesta (2009: p. 31), "this set of norms tries to guide and certify companies that are directed to environmental quality, describing performance standards based on environmental policy".

In 1996, NBR ISO 14001 was published, which deals with Environmental Management Systems, specification and guidelines for use. According to the United Nations Environment Program (2013), ISO 14001 is the most popular Environmental Management System in the world, being adopted by more than half of ISO's 164 national members.

Although the standards International Organization for Standardization (ISO) are not compulsory, companies started to join due to the competitive advantages, because consumers aware in the market and concerned about the environmentally correct consumption, started to acquire products and services from companies that work with the quality standards established by ISO 14001, through certification (Nicolella, Marques, \& Skorupa, 2004).

Environmental certification aims to establish guidelines and provide the necessary subsidies for the management of production processes and services, in order to reduce the environmental impacts caused by companies. Therefore, criteria are established for the enterprises to conduct their daily routine. The companies that have adhered to the environmental certification have already realized the gains that can be obtained, through the reduction of wastes and the implantation of ecological systems for consumption of water, electricity, among others. The environmental management system that is implemented to obtain environmental certification provides mechanisms for comparison between companies. Therefore, consumers can monitor the performance of organizations and choose to purchase the products and services of institutions that are meeting environmental standards (Nicolella, Marques, \& Skorupa, 2004).

Keeping an eye on this new and growing market share, micro and small businesses seek to meet the demands of the market. However, they run into the cost barrier for implementation and maintenance of certification. In order to assist micro and small companies in joining NBR ISO 14001, the Brazilian Micro and Small Business Support Service and the Brazilian Association of Technical Standards launched, in 2012, ABNT NBR ISO 14005 (ABNT, 2012). The environ- 
mental management standard guides the projects during the process of implementation of the requirements set forth in ABNT NBR ISO 14001, for the implementation of the Environmental Management System.

Sebrae and ABNT are constantly promoting training courses and lectures to educate micro and small entrepreneurs on the importance of compliance with standards as a way to increase profitability and contribute to the preservation of the environment.

Therefore, the next section aims to define micro and small enterprises in Brazil and their relation with the economic development of Brazil, bringing a panorama about micro and small companies and their relevance in this scenario.

\section{Micro and Small Enterprises and the Economic Development of Brazil}

With a dominant presence of smaller companies in Brazil, a growing trend in recent years, these organizations can increase their sustainability in the market, through the adoption of sustainable environmental practices-through education and environmental certification. This explanation is pertinent in relation to the main context of the article-environmental education as a stimulating tool for innovation and sustainability in an extremely competitive and voracious organizational market, since the information on micro and small companies reported below provides an accurate picture of these companies in Brazil, and how important it is to increase its permanence in the current market, generating besides environmental awareness, employment and income, which is the basis for the presence of this section.

According to Mota Filho (1996) the micro and small companies are part of the national culture being found, since the times of Brazil colony. However, the first official small business program known to have been created by the National Bank for Economic Development (BNDE) in 1960, through the establishment of the Executive Group for Assistance to Small and Medium Enterprises (GEAMPE), which recommended the expansion of financial support to these business units.

The term microenterprise or micro-entrepreneur only came to be known by the Brazilian legislator from Law No. 7256, of November 27, 1984, which established favored treatment and simplified micro-enterprises in the administrative fields, thus arising the status of the micro enterprise, which came from the Draft Law No. 16/1984. From then on the term microenterprise began to be part of the Brazilian legal and economic vocabulary.

For Souza (2001) it was from the creation of Law $n^{\circ} 7.256 / 1984$, that much was done by the Brazilian microenterprise. In this direction, MPE's are used as instruments of economic studies, and these studies are used as indexes of measurement of economic factors for the national economy, thus establishing a structure with respect to the generation of employment and income, attracting revenues for our country, in addition to forming in society an awareness of the strategic importance of small businesses in overcoming the economic and financial crisis. 
According to data released by the Brazilian Institute of Geography and Statistics (IBGE), in the 1980s, with the reduction of the economy's growth rate, resulting in a higher level of unemployment, small businesses started to be considered an alternative to the occupation of the hand of surplus labor, making the first concrete initiatives to encourage the opening of micro and small enterprises in the economy to emerge at the end of the decade (IBGE, 2001).

In the segment of micro-enterprises and small enterprises, much of the labor force is concentrated in the labor market. Therefore, the need for a differentiated look at these business units that play a key role in generating employment and income. According to a study carried out by Sebrae (2004), of the 3.6 million Brazilian companies that existed in 1998, $98.8 \%$ were micro and small companies, that is, the smaller units represented the vast majority of Brazilian companies.

The predominant presence of smaller companies is a result of the trend of increasing participation of microenterprises and small enterprises in total establishments and in employment over the last years, contributing significantly to leverage the Brazilian economy.

Still, according to Sebrae (2014) Brazil has about 8.3 million micro and small companies, which represent $99 \%$ of Brazilian companies. They generate about $70 \%$ of the new formal jobs, account for $40 \%$ of the wage bill and have a share of GDP of around $25 \%$.

The participation of MSEs in the country's productive structure has grown and strengthened in recent years. In the book, Micro and Small Enterprises: Labor Market and Development Implications, a diagnosis was made of the main aspects of MSE in the period 2000-2008. It was verified that these units generated $54 \%$ of the country's formal jobs, that is, half of created in the abovementioned period. In 2008 alone, small businesses generated an average of $20 \%$ of gross domestic product (GDP).

In world terms there is no concept that defines exactly the size of a company. In some countries the number of employees is used as criterion, as in most European Union countries, in others the criterion of billing as in Brazil.

In Brazil, Decree No. 5,028/2004 is currently in force and has amended the limits set in Law $n^{\circ}$ 9841/1999, which established the Statute of Microenterprise and Small Business, and Complementary Law 123/2006, which established the new Simplified Taxation System (SIMPLES NACIONAL), being a strictly tax law. The changes in the values established by these legal instruments are summarized in Table 1.

In addition to the criterion adopted in the Statute, the Brazilian Service for Support to Micro and Small Enterprises (Sebrae) uses the concept of employees in companies, as shown in Table 2.

The segment where micro and small companies are located in Brazil has its own specific characteristics and characteristics, starting with the heterogeneity of the sectors, such as: wholesale trade, retail trade, services, construction, finance, 
Table 1. Classification according to the gross annual revenue.

\begin{tabular}{ccc}
\hline Porte & $\begin{array}{c}\text { Status of MPE'S } \\
\text { (Decree No. 5028/2004) }\end{array}$ & $\begin{array}{c}\text { Simple national } \\
\text { (Complementary Law 123/2006) }\end{array}$ \\
\hline Micro enterprise & Up to R $\$ 433.75514$ & Up to R $\$ 360000.00$ \\
Small business & $\begin{array}{c}\text { Exceeding R } \$ 433755.14 \\
\text { and less than R } \$ 2133222.00\end{array}$ & $\begin{array}{c}\text { Exceeding R } \$ 360000.00 \\
\text { and less than R } \$ 3600000.00\end{array}$ \\
\hline
\end{tabular}

Source: Prepared by the authors, based on the MPE's statute and the federal revenue framework.

Table 2. Classification of companies by size and sector of activity.

\begin{tabular}{cccc}
\hline Porte/Sector & Trade and Services & services & Industry \\
\hline Micro enterprise & Up to 9 employees & Up to 9 employees & Up to 19 employees \\
Small business & From 10 to 49 employees & From 10 to 49 employees & From 20 to 99 employees \\
Average company & From 50 to 99 employees & From 100 to 499 employees \\
\hline
\end{tabular}

Source: Prepared by the authors, based on data from Sebrae/NA, 2013.

real estate, mining, transportation, among others. According to research by IBGE (2001), the segment that stands out most belongs to the activities of commerce and services, which are the economic sectors with the largest relative share of this business area.

It is also important to highlight the various characteristics of these units, their processes, products, forms of insertion in the productive structure, the forms of relationship with competitors, and the need to innovate. Therefore, the connection between micro and small companies and environmental education emerges as an extremely significant relationship to boost the possibility of these organizations staying in the Brazilian business market.

\section{Convergence of Environmental Education in Micros and Small Enterprises as a Factor of Innovation and Sustainability}

Micro and small enterprises face a number of challenges on a daily basis, among them the bureaucracy for access to credit, lack of managerial skills on the part of owners, poor qualification of labor, and difficulty in investing in research and development, as well as institutional difficulties to adopt environmental management.

However, it has already been realized that it is not only the lack of credit or investment by the government, but also the lack of skill, knowledge on the part of the entrepreneurs, who often have the habit of always doing the same business because they believe that if it is working with the competition, it will work for them as well. It is therefore a cultural issue. Therefore, it is essential to have an understanding of the importance of innovation for improving organizational performance. Promoting a change in the procedures and processes of small businesses stands out with a determining factor to reduce the high mortality rates of this segment. According to Schumpeter (1934: p. 7) "Historical and ir- 
reversible change in the way things are done is what we call "innovation" and which we define as changes in production functions that cannot be decomposed into infinitesimal stages".

In this context, the innovation process emerges as a differential for the micro and small entrepreneur who aims to make their enterprise more competitive and prepared to face the globalized market. For Schumpeter innovation may include "the opening of a new market, the acquisition of a new source of raw materials, or the structural reorganization of an industrial branch" (Schumpeter, 1934: p. 66).

One characteristic that can be found in the owners of the largest ventures in the world is the entrepreneurial feature. The entrepreneur stands out for his innovative profile and willingness to face and deliver to the business, being always willing to take the risk of opening and investing in the business that he considers feasible and feasible to be implemented.

As an innovation process for small enterprises, innovation focuses on environmental education as a strategy to achieve competitive advantage, as well as to reduce costs with inputs or production processes. With an eye to this growing market segment and concerned about the survival of MPEs, Sebrae, in partnership with the National Council for Scientific and Technological Development (CNPq), launched the Local Agents of Innovation Project (ALI), with the aim of disseminating culture of innovation in small capital.

The ALI program aims to act as an instrument transforming the reality of micro and small enterprises, helping to implant the culture of innovation by establishing an environment favorable to the sustainable flowering of small businesses. Local Innovation Agents evaluate the degree of innovation in companies that join the program free of charge. Each agent studies the reality to which the business is inserted and offers solutions according to the needs of each enterprise. In order to carry out the process, the agents carry out various visits to the companies, monitoring and supporting the implementation of the innovation actions indicated in a specific work plan. All actions are evaluated, approved and monitored by the entrepreneurs, so that they can continue the process.

The program uses the Innovation Radar methodology, which allows comparing the situation found in micro and small companies at the beginning of the problem and in later moments. The monitoring of the results allows us to know if the Program is being effective to improve the economic performance of MSEs, as well as to know the points that are working right or wrong, so that improvement can occur. It is believed that this methodology is effective, from the moment it provides subsidies for the comparison and analysis of the performance of companies before and after the implementation of the innovation process.

The Innovation Radar consists of a methodology based on 13 dimensions of innovation, which allows to evaluate the innovative maturity degree of micro and small companies. The radar methodology is composed of 12 dimensions of innovation described in the work of Professor Mohanbir Sawhney, director of the Center for Research in Technology \& Innovation, Kellogg School of Man- 
agement, USA, added by the innovative ambience dimension of Bachmann and Destefani. The 12 dimensions of innovation proposed by Sawhney et al. (2006) and complemented by Bachmann and Destefani (2008), are: supply, processes, customers, market, platform, brand, solutions, relationship, value added, organization, supply chain, network and innovative ambience.

For Santana \& Nunes (2013, p. 18) "it is not common to carry out actions of innovation with focus on the environment as a way to obtain competitive advantage or even to increase the efficiency of the processes". Such a statement may explain the difficulty that micro and small business owners have to view the environmental issue as an opportunity to leverage their business. A study published in the booklets on innovation in small businesses of Sebrae (Santana \& Nunes, 2013: p. 15) on the environment and innovation carried out in micro and small enterprises in the state of Sergipe, which joined the ALI Project of the textile and clothing segment, points out that micro and small entrepreneurs are not aware of the importance of the correct use of resources, "when asked about changes in inputs or processes, said that the activity of your company does not cause risks or negative environmental aspects". This shows the lack of vision and market knowledge, as consumers are increasingly seeking products and services that are environmentally friendly, in addition, of course, to contribute to the preservation of the environment for the present and future generations. In this situation, the utility of the use of the marketing tool and environmental certification comes as an adjunct to expand the life cycle of an organization of this size in the Brazilian business perspective.

\section{Environmental Marketing and the Role of Certification in the Sustainability of Micro and Small Enterprises}

The environmental problems on the planet we live in, such as: pollution of air, rivers, lakes, seas, depletion and deforestation of the soil, extinction of ani$\mathrm{mal} / \mathrm{plant}$ species, lack of water for human consumption, among others in the life of the population, and in particular of commercial establishments of any size, who wish to offer products and skilled and differentiated services to be enjoyed by this population. The discussion on the environmental issue contributed to the expansion of a contingent of organizations, which need to have their actions based on respect for nature. Thus, commercial establishments (services and products), suppliers, customers and public administration (State) are the main collectives that need to understand and internalize the concept of environmental marketing.

Production and consumption must respect the environment as a practice that is growing significantly, with a strong rise in modern enterprises, since there is a direct connection between the environmental impasses that are on the border of ecology - and the search for institutions by market and environmental sustainability and, of course, the search for a market differential vis-à-vis competitors in the segment in which it operates. 
The act of providing services and production has acquired an extremely strong ecological character these days. According to Dias and Zenone (2015), sustainable marketing-especially for companies that operate in extremely competitive markets or a society that is more informed and aware of its role-changes the way consumers are consumed and thus acquire products and services. Thus, in this scenario, the greatest challenge of these organizations is to incorporate this business philosophy into marketing strategies.

In this environmental context, companies with low market power-notably small and medium-sized companies, can develop competitive advantages (Porter, 1992), while companies in highly regulated sectors that are proactive in green marketing can apply the regulations and standards before forced to do so.

This is how environmental marketing expands with the objective of meeting the needs of current and future consumers, as well as the commercial organizations that market their products and services in the contemporary world.

Green or environmental marketing has a positive influence on various participants in the economy. The environment, developing economies, consumers, corporate strategy, product, production processes and the supply chain benefit from the sustainable efforts that are provided by the effective practice of environmental marketing in today's organizations.

Among the praiseworthy attitudes arising from these efforts are some opportunities that are the fruits of economic progress and advances in technology-present in our daily lives, ubiquitous and visible in large centers and also in cities of smaller housing size, such as actions that transform waste, debris and garbage, in huge opportunities through reuse, transforming trash into wealth, trash into energy, deformed into something well presented.

According to Dahlstrom (2012: p. 6), "Green Marketing is defined as the process of planning and executing the marketing mix to facilitate consumption, production, distribution, promotion, distribution, promotion, packaging, and product recovery in a way sensitive to ecological concerns". Green products are recognized nationally or internationally through certification and eco-labeling.

As described by Dias and Zenone (2015: p. 17), "producing and consuming are important for a country to grow and develop, but it is desirable, necessary and obligatory for this to be done in a sustainable way". There is, however, an impasse that sends small and medium-sized organizations to a corporate dilemma, since most of them only adhere to sustainable or green projects if they have an immediate gain. Changing this condition is a major obstacle to be overcome.

In order to reverse this situation, environmental certification is an indication of a possible and adequate solution, since soon every small and medium-sized company will have to reach its environmental certification, otherwise it will be out of the competition for new markets and consumers.

The corporation that has the environmental certification will be qualified in the dispute for new consumer markets, and otherwise, the difficulties will be considerable, culminating in determining its unsustainability and non-permanence 
in the strong environment of fierce globalized business environment. Certification also plays an important role for small and medium-sized organizations, and it must be taken into account that ecologically correct products are welcome in the international market (Dias, 2014), and can also provide a breadth of merchandise in their performance corporate governance.

This shows that organizations investing in certification can simultaneously value nature and the company, as can be seen in Table 3. Thus, the advantage has a double meaning, with importance of great amplitude for the two directions: environment and companies.

The essence of these advantages listed in the table for SMEs translates into a simultaneous sustainability, since the environment and the organization benefit from obtaining the advantages presented.

Simultaneous sustainability validates what Tercek and Adams (2014: p.15) claim: "Nature is not only the basis of human well-being but also the best commercial investment that any government or business can make". In this case, despite the fact that the environment is a market niche with splendid potential to be better researched by private or public companies, literature reports that small and medium-sized companies are still in preliminary stages regarding environmental practices. The degree to which SMEs are too informally so far-can be considered as an obstacle to proactive environmental management.

In this sense, SME management should be made more judicious, and environmental certification can be useful. The certification brings a managerial leap for the company, which establishes procedures with a high quality standard, which can generate savings in energy expenditures and also in purchase with inputs. In addition, environmental seals are required in various bidding processes and help in business.

It is therefore verified that MSEs need an environmental system adequate to their processes, which is useful in demonstrating their environmental commitment, since in the world market, as Dias (2014) argues, green advertising is cause

Table 3. Advantages of obtaining ISO 14001 certification_-SMEs (França, 2015).

\begin{tabular}{ll}
\hline 1 & Control of environmental aspects and impacts of the organization \\
2 & Gain in the image of the organization-Strengthening the concept of sustainability \\
3 & Stakeholder satisfaction \\
4 & Knowledge and compliance with applicable legal requirements \\
5 & Customer confidence \\
6 & Reduction of costs \\
7 & Condition to stay in the market (sustainability) \\
8 & Possibility to export \\
9 & Avoid environmental fines that can make the business unfeasible \\
10 & Lower interest financing
\end{tabular}

Source: Adapted by the authors. Available at: http://www.qmsbrasil.com.br/blog/. 
increasingly popularized "In which some products are touted as ecological, be they originate in organic plantations, or because they are free of substances that are aggressive to the environment. In this way, environmental certifications and labeling are increasingly becoming a guarantee that the declared environmental attributes are real".

In this way, environmental certifications-are decisive for the sustainability of small and medium enterprises, since these are now elements that prolong the organizational life cycle-in an environment of high business competitiveness. Today it is considered a trend for most organizations in the world and encompasses various mechanisms to ensure the protection of the environment from the exploitation of natural resources and the process of industrialization.

As can be seen in Figure 1, ISO 14001 certification has been expanded in Brazil.

From 2013 to 2018, the growth of ISO 14,000 certifications in Brazil is observed. Specifically in 2018, an unfinished period, it is verified that certifications recertified, expired and valid total 2577 certifications. There has been an increase in the number of certifications when analyzing the last five years. This growth is an indicator that companies have realized that 14,000 certification has become critical in the extremely competitive context of modern organizations regardless of their size.

The ISO 14000 series has multiple standards, the best known being ISO 14001, but it is not the only one. There are several others with various specifications regarding environmental management, as shown in Table 4.

The ISO 14001 standard guides and gives subsidies for the implementation of the Environmental Management System, and is therefore the most important standard of the ISO 14000 series. It is also the only ISO 14000 auditable standard, and therefore, the only one that companies implement. ISO 14001 demonstrates commitment to sustainable practices.

It is important to emphasize the costs of implementing an Environmental Management System (EMS) or ISO 14.001-there is no pre-determined table with them, but it is known that they are not popular. There are several factors that must be taken into account in relation to the composition of the final cost: what ISO standard to implement, training and qualification, innovation to be implemented, time, cost of certification audits and maintenance of them. Few companies believe in prevention, and others end up spending real fortunes with

Table 4. Environmental management standards.

\begin{tabular}{ll}
\hline ISO 14001 & Standards regarding the implementation of the EMS. \\
ISO 14004 & Standards on the EMS, but aimed at the internal part of the company. \\
ISO 14010 & Standards related to environmental auditing and its credibility. \\
ISO 14031 & Standards on the performance of the EMS. \\
ISO 14020 & Standards related to environmental labels and declarations.
\end{tabular}

Source: Available in: https://www.normastecnicas.com/iso/serie-iso-14000/. 
environmental jurisdictions or disburse exorbitant amounts to implant an EMS urgently as required by the competent bodies and justice (Roche, 2018).

In this way, the implementation cost for small and medium-sized companies ends up being a necessary investment, despite being a significant outlay. However, these companies have no alternative, since such occurrence will be essential in the medium or short term. To stay or expand your market, you will have to seek certification. The future strategic scenarios signal: it is certifying or disappearing, accelerating the stage of the organization's life cycle-“decline" and following, the bankruptcy of the institution.

\section{Conclusion}

The search has searched to analyze environmental education as a competitive differential for small businesses. For this, environmental education and sustainability were analyzed; as well as the environmental certification and NBR ISO 14001; micro and small enterprises and the economic development of Brazil; the relationship between innovation and micro and small enterprises, and, finally, environmental marketing and the role of certification in the sustainability of small and medium-sized enterprises. The discussions sought to understand and relate environmental education as an innovation tool for micro and small companies. Small capital has several reasons for adhering to environmental standards, such as the growing market demand for environmentally correct products and services, reduction of production and input costs, and conservation of natural resources.

However, in the course of the research it was verified that micro and small entrepreneurs still do not see environmental management as a strategy of innovation, which can contribute to increasing the profitability of the organization and consequently guarantee survival in the market.

The culture of innovation plays a crucial role in maintaining the competitiveness of enterprises. When it comes to micro and small businesses, it is perceived that this role becomes much more important, since it contributes to the greater longevity of these businesses, helping to reduce their fragilities.

With the globalization of the economy the market has become dynamic, requiring daily changes in the process of business operation. Therefore, micro and small entrepreneurs need to know the segment to which they are inserted, and the needs of consumers and seek ways to innovate their production processes, their products and services, improve the way the company deals with the external public, and above of everything convey to customers trust, credibility and respect.

The process of innovation for the environment emerges not only as a competitive differential, but also as a factor that can be determinant for the survival of micro and small enterprises. Therefore, it is believed to be important the investment by federal, state and municipal governments in public policies that can help small businesses to adhere to environmental norms, as well as the invest- 
ment by the institutions that work with these business units, as the Brazilian service of support to micro and small companies, in programs that help to unfold the culture of innovation for the environment.

The environmental certification (ISO 14.001) is a way that small and medium-sized companies have to demonstrate that they fit into sustainability actions, seek out new markets, and become competitive and recognized as environmentally friendly companies. What motivates them to seek official recognition is the legitimacy and the competitive differential that this represents. Thus, despite the high cost of implementing environmental certification, in the medium and long term certification will be a factor excluding the company from the market if it does not seek to be certified.

From the above, it is believed that it is of essential importance the existence of public policies to encourage MSEs to adhere to environmental norms for the implementation of environmental certifications, since these actions contribute to both the survival of these enterprises and the preservation of the environment. In short, environmental education in small and medium-sized enterprises, allied with innovation, is a relevant factor of corporate sustainability, and still-an environmental preservation factor.

\section{Conflicts of Interest}

The authors declare no conflicts of interest regarding the publication of this paper.

\section{References}

Associação Brasileira de Normas Técnicas (ABNT) (2004). NBR ISO 14001: Sistemas da gestão ambiental-Requisitos com orientação para uso (2nd ed.). Rio de Janeiro: ABNT.

Associação Brasileira de Normas Técnicas (ABNT) (2012). NBR ISO 14005: Diretrizes para a implementação em fases de um sistema de gestão ambiental, incluindo o uso de avaliação de desempenho ambiental. Rio de Janeiro: ABNT.

Bachmann, D. L., \& Destefani, J. H. (2008). Metodologia para estimar o grau das inovaçóes nas MPE. Curitiba: Sebrae.

Brasil (1999). Dispõe sobre a educação ambiental, institui a Política Nacional de Educação Ambiental e dá outras providências. Lei No. 9.795, Brasília.

Cadastro Geral de Empregados e Desempregados (CAGED) (2018). Postos formais de trabalho.

http://bi.mte.gov.br/eec/pages/consultas/evolucaoEmprego/consultaEvolucaoEmprego. xhtml\#relatorioSubSet

Certificados Válidos no Brasil (2018). Certifiq-Sistema de Gerenciamento de Certificados/INMETRO.

https://certifiq.inmetro.gov.br/Grafico/HistoricoCertificadosConcedidos

Dahlstrom, R. (2012). Gerenciamento de marketing verde. São Paulo: Cengage Learning.

Dias, R. (2014). Marketing Ambiental: Ética, responsabilidade social e competitividade nos negócios. São Paulo: Atlas.

Dias, R., \& Zenone, L. C. (2015). Marketing Sustentável: Valor social, econômico e 
mercadológico. São Paulo: Atlas.

França (2015). E-Book ISO 14001:2015-QMS Certification Services. Neifer. http://qmsbrasil.com.br/certificacao-iso-14001/

http://qmsbrasil.com.br/wp-content/uploads/2018/06/eBook_14001-ilovepdf-compress ed.pdf

Giesta, L. C. (2009). Educação ambiental e sistema de gestão ambiental em empresas. Tese de doutorado do Programa de Pós-Graduação em Administração da Universidade Federal do Rio Grande do Sul.

IBGE (2001). Estudos e Pesquisas-Informação Econômica. As micro e pequenas empresas comerciais e de serviços no Brasil: 2001/IBGE, Coordenação de Serviços e Comércio. Instituto Brasileiro de Geografia e Estatística, Rio de Janeiro.

Jacobi, P., Raufflet, E., \& Arruda, M. P. (2011). Educação para a sustentabilidade nos cursos de administração: Reflexão sobre paradigmas e práticas. RAM. Revista de Administração Mackenzie, 12, 21-50.

Layrargues, P. P. (1998). Educação para a gestão ambiental: Será esta a sucessora da educação ambiental? In S. F. Mata et al. (Eds.), Educação ambiental, desafio do século: Um apelo ético (pp. 108-113). Rio de Janeiro: Terceiro Milênio.

Mota Filho, M. (1996). A Revolução dos Pequenos. Brasília: Sebrae.

Nicolella, G., Marques, J. F., \& Skorupa, L. A. (2004). Sistema de gestão ambiental: Aspectos teóricos e análise de um conjunto de empresas da região de Campinas, SP. Jaguariúna: Embrapa Meio Ambiente.

Porter, M. E. (1992). Vantagem competitiva: Criando e sustentando um desempenho superior. Rio de Janeiro: Campus.

Quintas, J. S. (2004). Educação no processo de gestão ambiental: Uma proposta de educação ambiental transformadora e emancipatória. In P. P. Layrargues (Ed.), Identidades da educação ambiental brasileira (pp. 113-140). Brasília: Ministério do Meio Ambiente, Diretoria de Educação Ambiental.

Roche, R. (2018). Quanto custa implantar uma gestão ambiental no meu negócio? http://robertoroche.com.br/Artigos/quanto-custa-implantar-uma-gestao-ambiental-no -meu-negocio

Santana, E. M., \& Nunes, M. A. S. N. (2013). Meio ambiente \& inovações realizadas nas micro e pequenas empresas de confecção de Sergipe. Cadernos de Inovação em Pequenos Negócios: Indústria, 1.

https://bibliotecas.sebrae.com.br/chronus/ARQUIVOS_CHRONUS/bds/bds.nsf/9aba2 bd685684cca76f809fd4cf1e3e2/\$File/5153.pdf

Sawhney, M., Wolcott, R. C., \& Arroniz, I. (2006). The 12 Different Ways for Companies to Innovate. MIT Sloan Management Review, 47, 74-81.

Schumpeter, J. A. (1934). Teoria do desenvolvimento econômico: Uma investigação sobre lucros, capital, crédito, juro e o ciclo econômico. Tradução de Maria Sílvia Possas. Coleção os economistas. São Paulo: Nova Cultural.

Sebrae (2004). Boletim Estatístico de Micro e Pequenas Empresas. Brasília: Gráfica Charbel.

Sebrae (2013a). Inovação em sustentabilidade: Ferramenta de educação ambiental. Relatório de Inteligência Sintético.

Sebrae (2013b). Sobrevivência das empresas no Brasil. Brasília.

Sebrae (2013c). Cadernos de Inovação em Pequenos Negócios: Indústria (Vol. 1, No. 1). Brasília: Sebrae, CNPq. 
https://bibliotecas.sebrae.com.br/chronus/ARQUIVOS_CHRONUS/bds/bds.nsf/9aba2 bd685684cca76f809fd4cf1e3e2/\$File/5153.pdf

Sebrae (2014). MPE BRASIL Prêmio de Competitividade para Micro e Pequenas Empresas. Brasília.

Sebrae (2018). Panorama Sebrae 2018.

https://datasebrae.com.br/wp-content/uploads/2018/06/Panorama-Sebrae

Souza, G. E. A. (2001). Mortalidade das Micro e Pequenas Empresas do Comércio Varejista de Rio Branco: Principais determinantes do insucesso. Rio Branco: Sebrae.

Tercek, M. R., \& Adams, J. S. (2014). Capital Natural: Como as empresas e a sociedade podem prosperar ao investir no meio ambiente. São Paulo: Alaúde Editorial.

UNESCO (2014). Conferência Mundial sobre Educação para o Desenvolvimento Sustentável exige renovação de compromisso por parte de todos os países. Nagóia.

http://www.unesco.org/new/pt/brasilia/about-this-office/single.view/news/world_confe rence_on_education_for_sustainable_development_ca 